\title{
Sistem Informasi Eksekutif Pelelangan dengan Metode Iconix Process Pada PT. Pelindo I Berbasis Web
}

\author{
Dedek Indra Gunawan Hutasuhut ${ }^{1, *}$, Ambiyar ${ }^{2}$, Nita Syahputri ${ }^{1}$, Ulfa Indriani ${ }^{1}$, Ermayanti Astuti ${ }^{1}$, \\ Unung Verawardina ${ }^{2,3}$ \\ ${ }^{1}$ Fakultas Teknik dan Ilmu Komputer, Sistem Informasi, Universitas Potensi Utama, Medan, Indonesia \\ ${ }^{2}$ Fakultas Teknik, Teknologi Pendidikan dan Kejuruan, Universitas Negeri Padang, Padang, Indonesia \\ ${ }^{3}$ Program Studi Pendidikan Teknologi Informasi dan Komputer, IKIP PGRI, Pontianak, Indonesia \\ Email: 1,*dedek.indra@gmail.com, ${ }^{2}$ ambiyar@ft.unp.ac.id, ${ }^{3}$ nieta20d@gmail.com, ${ }^{4}$ nieta20d@gmail.com, \\ ${ }^{4}$ ulfahindriani90@gmail.com, ${ }^{5}$ ermaemma0216@gmail.com, ${ }^{6}$ unungverawardina@gmail.com \\ Email Penulis Korespondensi: dedek.indra@gmail.com
}

\begin{abstract}
Abstrak-Kemajuan teknologi informasi memiliki dampak yang luar biasa dalam membantu pihak eksekutif dalam mengambil keputusan. Sistem informasi eksekutif merupakan salah satu metode yang terbaik untuk membantu pihak pimpinan atau eksekutif untuk mengambil keputusan secara efektif dan efisien. Tidak semua pekerjaan dan pengadaan barang dilakukan oleh karyawan atau staff PT. Pelindo I akan tetapi dilakukan dengan proses lelang. Selama ini proses pendataan yang dilakukan adalah dengan menggunakan Microsoft excel. Banyak kelemahan yang terjadi yaitu data tidak realtime dan pimpinan tidak dapat melihat informasi secara langsung serta data yang ditampilkan belum dapat membantu pimpinan mengambil keputusan secara cepat. Oleh karena itu dibutuhkan Sistem Informasi Eksekutif agar pimpinan dapat melihat langsung status pelelangan yang ada pada PT. Pelindo I. Tujuan dari penelitian ini adalah merancang dan membangun sistem informasi eksekutif pada PT. Pelindo I dengan metode iconix process untuk menampilkan status pelelangan.Tahapan-tahapan dalam merancang aplikasi menggunakan metode Iconix Process yang terdiri dari sembilan tahapan yaitu proses requirement analysis, penyusunan domain model, GUI storyboard, use case diagram, robustness diagram, sequence diagram, update domain model, class diagram, implementation. Hasil dari penelitian ini adalah menghasilkan aplikasi yang menampilkan laporan status pelelangan yang ada pada PT. Pelindo pada tahun 2019 yang lebih efisien dengan menggunakan metode iconix process. Laporan yang ditampilkan berupa data selesai kontrak, masih proses, gagal dan dikembalikan.
\end{abstract}

Kata Kunci: Sistem Informasi Eksekutif, Iconix Process, Status Lelang

Abstract-The advancement of information technology has had a tremendous impact in assisting executives in making decisions. The executive information system is one of the best methods to help the leader or executive to make decisions effectively and efficiently. Not all work and procurement of goods is carried out by employees or staff of PT. Pelindo I, however, was carried out through an auction process. So far, the data collection process has been done using Microsoft Excel. Many weaknesses that occur, namely the data is not realtime and the leader cannot see the information directly and the data displayed cannot help the leader make decisions quickly. Therefore, an Executive Information System is needed so that the leadership can see directly the status of the existing auction at PT. Pelindo I. The purpose of this research is to design and build an executive information system at PT. Pelindo I with the iconix process method to display the status of the auction. The stages in designing an application using the Iconix Process method consist of nine stages, namely the process of requirements analysis, preparation of a domain model, GUI storyboard, use case diagrams, robustness diagrams, sequence diagrams, domain updates model, class diagram, implementation. The result of this research is to produce an application that displays a report on the status of the existing auction at PT. Pelindo in 2019 which is more efficient by using the iconix process method. The report that is displayed is in the form of data on contract completion, still in process, failed and returned.

Keywords: Executive Information System; Iconix Process; Auction Status

\section{PENDAHULUAN}

Kemajuan teknologi informasi diciptakan untuk mempermudah, menghemat waktu serta mempercepat dalam pengambilan keputusan. Salah satu teknologi dalam mempercepat pengambilan keputusan yang strategis bagi eksekutif adalah dengan menggunakan Sistem Informasi Eksekutif (SIE)[1]. Dengan adanya Sistem Informasi Eksekutif, pimpinan dapat memantau data status pekerjaan dimana saja tanpa mengenal jarak. Sistem informasi eksekutif merupakan modul dalam sistem pendukung kuputusan [2] yang digunakan untuk membantu mengambil kebijakan maupun keputusan[3]. Sistem pengambilan keputusan telah banyak digunakan dalam berbagai bidang seperti pendidikan [4], [5] pekerjaan [6], [7] maupun pertanian[8], [9].

Tidak semua pekerjaan dan barang yang ada pada PT. Pelindo I dikerjakan oleh karyawan tetapi dilakukan dengan proses lelang. Dalam proses pembuatan laporan lelang pada PT. Pelabuhan Indonesia I (Pelindo I) masih terdapat kekurangan yaitu pembuatan laporan status pekerjaan dan pengadaan barang masih bersifat semi komputerisasi hanya menggunakan MS. Excel belum menggunakan sistem yang teraplikasi khusus. Dengan sistem semi komputerisasi tersebut masih sering timbul permasalahan yang terjadi yaitu dalam proses pembuatan laporan dan penyimpanan data yang terkait dengan status pekerjaan dan pengadaan barang. Masalah yang sering terjadi adalah ketika update data yang hampir setiap hari dilakukan, sehingga membutuhkan waktu yang cukup lama dalam proses penambahan data, pengurangan data hingga pembuatan laporan serta sulitnya mencari kembali data customer karena tidak tersimpan ke database. Dengan demikian akan menyulitkan pimpinan dalam mengambil keputusan customer mana yang akan menjadi pemenang dalam proses lelang. 
Kebutuhan PT. Pelindo atas bantuan dari pihak ketiga dalam hal ini disebut dengan customer tentu harus difasilitasi dengan baik. Selama ini customer tidak dapat melihat kebutuhan dan status pengajuan pekerjaan dan pengadaan barang yang ada pada PT. Pelindo I secara langsung. Hal ini dapat menyebabkan terlambatnya pekerjaan dan pengadaan barang.

Untuk mengatasi hal tersebut maka diperlukan sistem informasi eksekutif untuk memantau status pekerjaan dan pengadaan barang yang lengkap. Dengan adanya sistem informasi eksekutif maka pimpinan dapat mengambil keputusan dengan cepat dan customer dapat melihat status pekerjaan dan pengadaan barang yang diajukan. Begitu juga dengan penelitian yang dilakukan oleh Prayitno [3] yang menghasilkan Sistem Informasi Eksekutif Pemasaran yang lengkap dan praktis dengan menggunakan metode drill down. Perancangan Sistem Informasi Eksekutif juga telah dilakukan untuk merancang data warehouse sehingga dapat membantu pimpinan untuk mengambil kebijakan serta untuk kebutuhan [10], [11], [12].

Menurut Elmarie [13], sistem informasi eksekutif merupakan sebuah alat untuk membantu management dan pimpinan untuk mengambil keputusan dan penyelesaian masalah. Pada survey yang telah dilakukannya sebanyak $60 \%$ atau sebanyak 38 perusahaan dari 65 perusahaan ingin menerapkan sistem informasi eksekutif pada perusahaannya.

Salah satu metode yang dapat digunakan untuk membuat sistem informasi eksekutif adalah dengan menggunakan metode Iconix Process. Seperti penelitian yang dilakukan oleh Dharmawan [14] yang merancang web untuk strategi penjualan agar lebih efektif dan efisien. Berdasarkan analisis kebutuhan yang disebutkan pada penelitian tersebut maka peneliti merancang aplikasi menggunakan metode Iconix Process. Pada penelitian tersebut menghasilkan sebuah aplikasi e-commerce penjualan barang elektronik.

Begitu juga penelitian yang dilakukan oleh Amirul [15] yang bertujuan untuk membuat aplikasi absensi untuk peningkatan kinerja HRD dengan menggunakan metode Iconix Process. Metode Iconix Process memudahkan peneliti untuk merancang aplikasi absensi.

Metode Iconix Process juga digunakan untuk mendesain sistem informasi entrepreneurship yang dilakukan oleh A. Pratama 2019 [16]. Penelitian tersebut mengembangkan sistem informasi kewirausahaan mahasiswa untuk menampung dan mempromosikan semua produk dan layanan setiap unit bisnis mahasiswa.

Berdasarkan beberapa penelitian tersebut, maka metode Iconix Process dapat digunakan untuk merancang Sistem Informasi Eksekutif yang menampilkan data status pekerjaan dan pengadaan barang pada PT. Pelindo I berbasis web. Sistem yang dibangun menggunakan bahasa pemprograman PHP dan data base MySql. Data yang ditampilkan pada Sistem Informasi Eksekutif berupa grafik sehingga pihak eksekutif dapat melihat status pekerjaan secara update begitu juga penelitian yang dilakukan oleh [17], [18].

\section{METODOLOGI PENELITIAN}

\subsection{Tahapan Penelitian}

Penelitian ini menggunakan Sistem Informasi Eksekutif pada PT. Pelindo I Medan untuk membantu eksekutif mengambil keputusan berdasarkan data laporan yang telah ada. Pengumpulan data dilakukan dengan cara wawancara berdasarkan data yang telah ada pada PT. Pelindo I tahun 2019. Tahapan penelitian dalam merancang Sistem Informasi Eksekutif pada PT. Pelindo dapat dilihat pada Gambar 1.

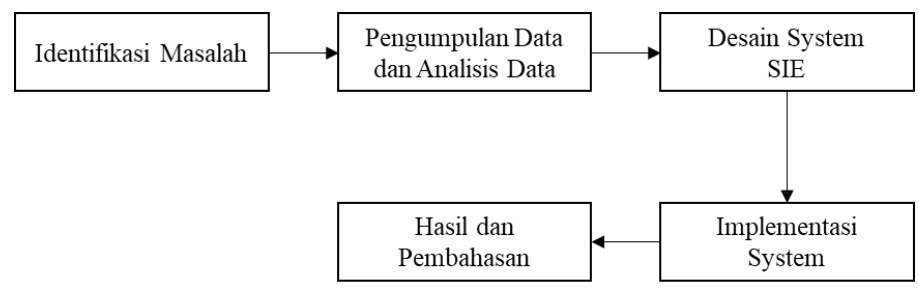

Gambar 1. Tahapan Penelitian

1. Identifikasi Masalah, pada tahapan ini peneliti merumuskan masalah yang ada pada PT. Pelindo I terkait dengan Status Pekerjaan dan Pengadaan Barang. Masalah-masalah yang ada seperti pencatatan masih menggunakan Microsoft excel sehingga eksekutif tidak dapat memantau laporan secara langsung. Oleh karena itu dibutuhkan sebuah Sistem Informasi Eksekutif agar pihak eksekutif dapat melihat secara realtime laporan yang ada secara langsung.

2. Pengumpulan data dilakukan dengan cara wawancara dari pegawai PT. Pelindo I. Data yang digunakan adalah tahun 2019 yang terlihat pada Tabel 1.

Tabel 1. Data Status Pekerjaan dan Pengadaan Barang Tahun 2019

\begin{tabular}{lc}
\hline \multicolumn{1}{c}{ Status Harian } & Permintaan \\
\hline Selesai - Kontrak & 27 \\
Selesai - Pengadaan & 18 \\
Selesai - Obsolete & 0 \\
\hline
\end{tabular}


JURNAL MEDIA INFORMATIKA BUDIDARMA

Volume 5, Nomor 2, April 2021, Page 387-397

ISSN 2614-5278 (media cetak), ISSN 2548-8368 (media online)

Available Online at https://ejurnal.stmik-budidarma.ac.id/index.php/mib DOI 10.30865/mib.v5i2.2746

\begin{tabular}{lc}
\hline \multicolumn{1}{c}{ Status Harian } & Permintaan \\
\hline Proses - Penawaran & 3 \\
Proses - Penetapan Pemenang & 0 \\
Proses - Pengadaan / Lelang & 0 \\
Proses - Perencanaan & 9 \\
Proses - Rapat Penjelasan & 2 \\
Proses - Verifikasi Permintaan & 4 \\
Proses - Permintaan Ditolak & 9 \\
Proses - Permintaan Ditolak & 9 \\
Proses - Rapat Penjelasan (Enwijing) & 0 \\
Proses - Undangan Lelang & 2 \\
Proses - Penyiapan Dokumen Lelang & 0 \\
Proses - Selesai Lelang & 15 \\
Proses - Evaluasi & 6 \\
Proses - Negosiasi & 12 \\
Proses - Verifikasi Pemenang & 0 \\
Dikembalikan & 18 \\
Kontrak Pra-Go Live & 0 \\
Data Eror & 2 \\
Belum Diproses & 8 \\
Gagal & 13 \\
\hline
\end{tabular}

3. Analisa Data, data yang telah diperoleh pada Tabel 1 kemudian dianalisa sebagai bahan untuk proses selanjutnya.

4. Desain Sistem Informasi Eksekutif, pada tahap ini dilakukan proses desain SIE untuk melihat status pekerjaan dan pengadaan barang pada PT. Pelindo I. Adapun proses pelelangan pekerjaan dan pengadaan barang adalah sebagai berikut:

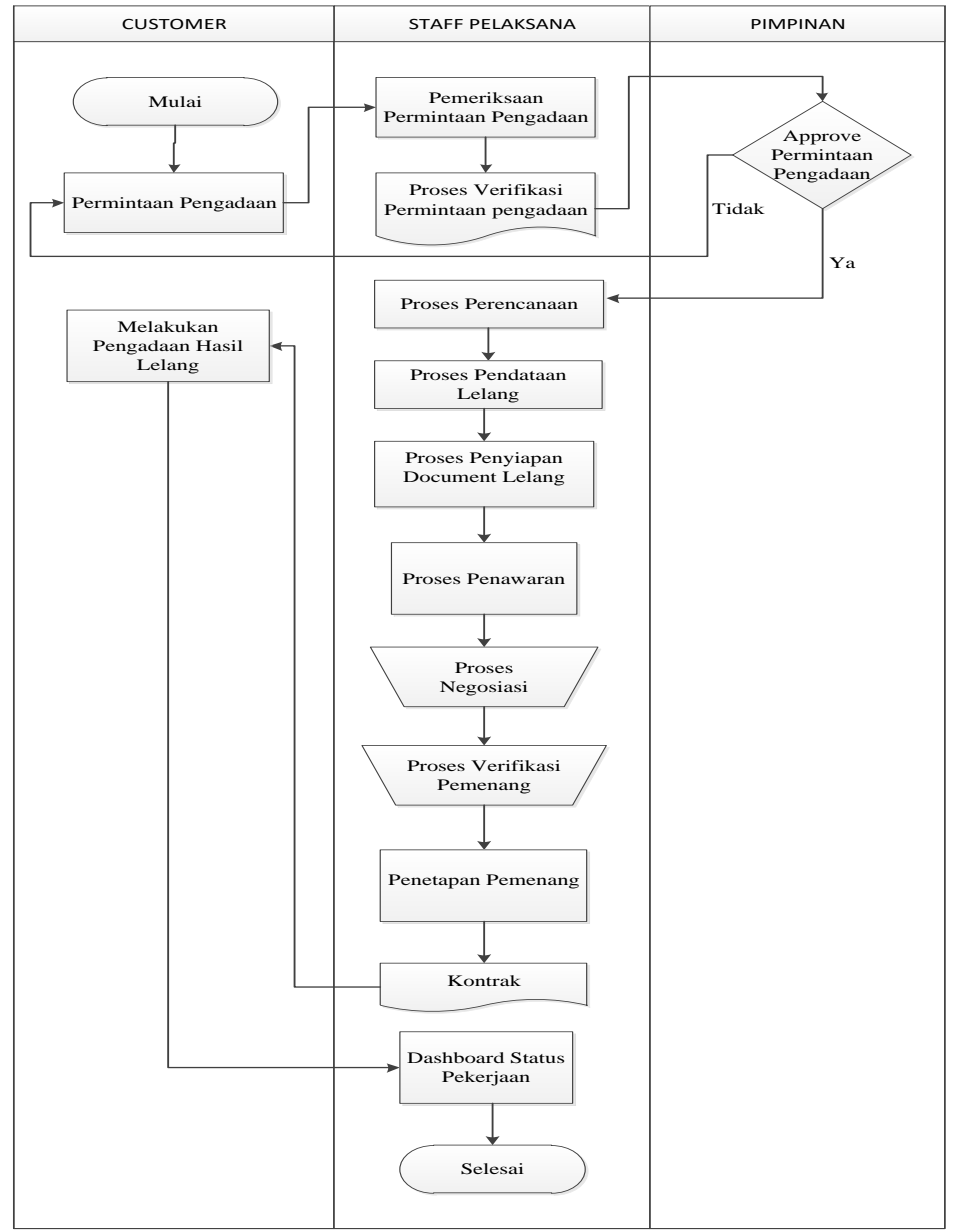

Gambar 2. Proses Pelelangan 


\section{JURNAL MEDIA INFORMATIKA BUDIDARMA}

Volume 5, Nomor 2, April 2021, Page 387-397

ISSN 2614-5278 (media cetak), ISSN 2548-8368 (media online)

Available Online at https://ejurnal.stmik-budidarma.ac.id/index.php/mib DOI 10.30865/mib.v5i2.2746

Adapun penjelasan dari Flow Of Document (FOD) diatas yaitu sebagai berikut:

a. Customer request permintaan pengadaan.

b. Permintaan pengadaan masuk ke email (Staff Pelaksana).

c. Pemeriksaan permintaan pengadaan.

d. Staff Pelaksana melakukan verifikasi permintaan pengadaan.

e. Pimpinan approve permintaan pengadaan.

f. Staff Pelaksana melakukan proses perencana.

g. Staff Pelaksana melakukan proses pendataan lelang seperti berikut:

1. Proses penyiapan dokumen lelang

2. Proses penawaran

3. Proses negosiasi

4. Proses verifikasi pemenang

5. Proses penetapan pemenang

6. Selesai Kontrak

h. Customer dapat melakukan pengadaan sesuai dengan permintaan

i. Status Pekerjaan.

5. Implementasi, setelah desain dibangun maka aplikasi akan diterapkan di PT. Pelindo I. Aplikasi digunakan oleh karyawan PT. Pelindo.

6. Hasil dan Pembahasan, pada tahap ini peneliti akan menampilkan hasil dan membahas tentang aplikasi yang dihasilkan berdasarkan metode yang diterapkan.

\subsection{Iconix Process}

Iconix Process merupakan metode yang digunakan untuk membangun sistem perangkat lunak berbasis skenario yang bertujuan untuk menghasilkan desain berorientasi objek yang kemudian dapat dikodekan. Iconix Process terbagi dua yaitu Dynamic dan Static[19]. Desain metode Iconix Process dapat terlihat pada gambar di bawah ini

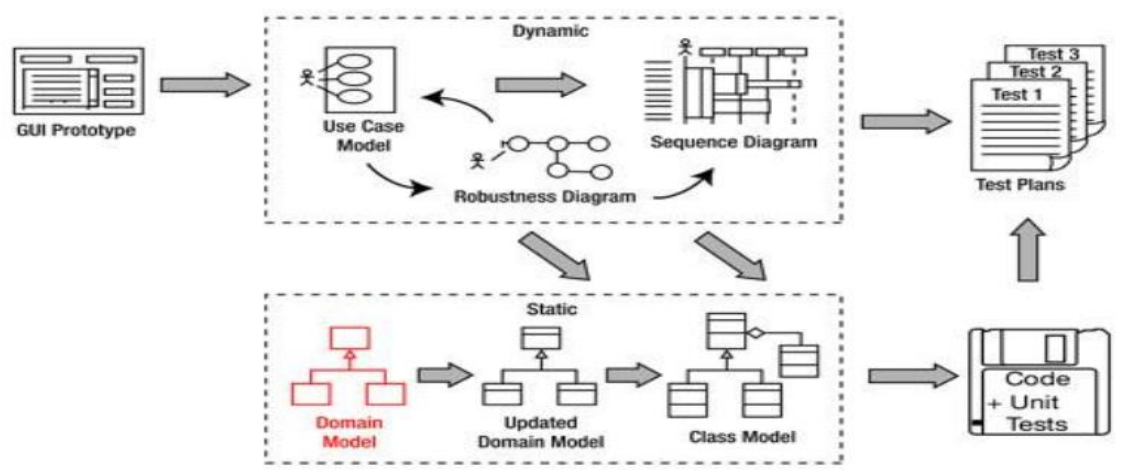

Gambar 3. Iconix Process [15]

Untuk menghubungkan skenario ke objek dilakukan dengan 4 tahap yaitu requirements, Analysis and Preliminary Design, Detailed Design dan Implementation[14].

1. Requirements

a. Functional Requirements

Pada skenario ini data-data yang dibutuhkan akan dikumpulkan dan diolah untuk pembangunan perangkat lunak.

b. Domain Modeling

Kebutuhan perangkat lunak yang bersifat fungsional maupun non fungsional didapatkan pada skenario statis yang telah diekstrak.

c. GUI Storyboard

Antarmuka pengguna akan ditampilkan pada tahapan ini.

d. Use Case Modeling

Mengidentifikasi aktifitas yang dilakukan oleh aktor terhadap proses pelalangan.

2. Analysis and Preliminary Design

a. Robustness Analysis

Penggunaan Robustness Diagram adalah untuk membantu menjembatani keberadaan ruang kosong dari analisis desain aktual dengan implementasi pengkodean.

b. Update Domain Model

Menghilangkan class yang redundant atau ambigu serta menambahkan beberapa class yang tidak ada serta atribut di dalam pemodelan domain.

3. Detailed Design

a. Sequence Diagram 


\section{JURNAL MEDIA INFORMATIKA BUDIDARMA}

Volume 5, Nomor 2, April 2021, Page 387-397

ISSN 2614-5278 (media cetak), ISSN 2548-8368 (media online)

Available Online at https://ejurnal.stmik-budidarma.ac.id/index.php/mib

DOI 10.30865/mib.v5i2.2746

Tahapan pemodelan sequence diagram di mana disusun terhadap diagram alir yang dilanjutkan dari tahapan robustness diagram.

b. Update Domain Model

Tahapan penambahan model yang didasarkan pada hasil pengembangan sequence diagram yang disesuaikan terhadap kebutuhan perangkat lunak.

4. Implementation

\section{a. Coding/Unit Testing}

Setelah model dirancang maka selanjutnya adalah proses pembuatan coding.

b. Integration and Scenario Testing

Setelah pembuatan coding selesai maka proses selanjutnya adalah pengujian sistem. Tahapan yang dilanjutkan setelah proses pembuatan coding atau proses penerjemahan ke dalam tahapan pengujian (testing).

\section{HASIL DAN PEMBAHASAN}

Hasil dari penelitian adalah merancang Sistem Informasi Eksekutif Lelang pada PT. Pelindo I menggunakan metode Iconix Process. Metode Iconix Process terdiri dari 4 tahapan yaitu:

\subsection{Functional Requirements}

Langkah pertama pada metode Iconix Process adalah menentukan requirement. Adapun kebutuhan dalam perancangan sistem informasi eksekutif lelang pada PT. Pelindo I adalah sebagai berikut:

1. Data customer

2. Data pengadaan

3. Data kontrak

4. Data laporan

\subsection{Domain Model}

Langkah kedua adalah adalah merancang domain model berdasarkan data kebutuhan yang telah didapatkan sebelumnya.

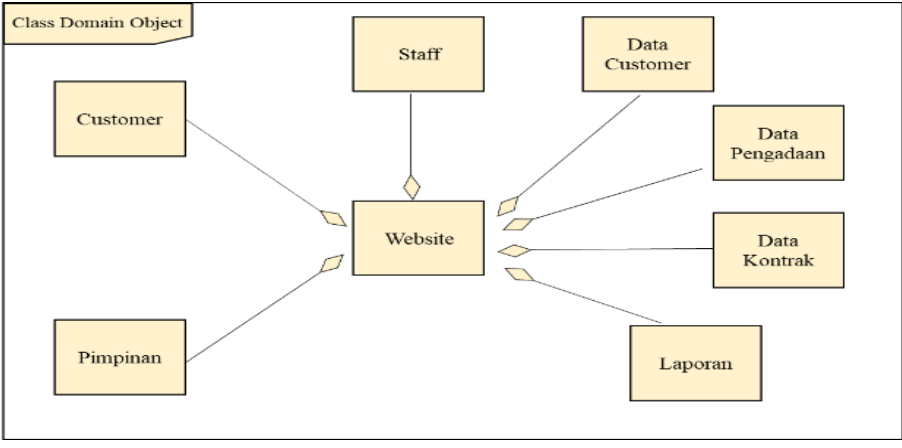

Gambar 4. Domain Model

\subsection{GUI Storyboard}

Langkah ketiga adalah merancang desain antarmuka pada sistem informasi eksekutif menggunakan metode Iconix Process adalah sebagai berikut:

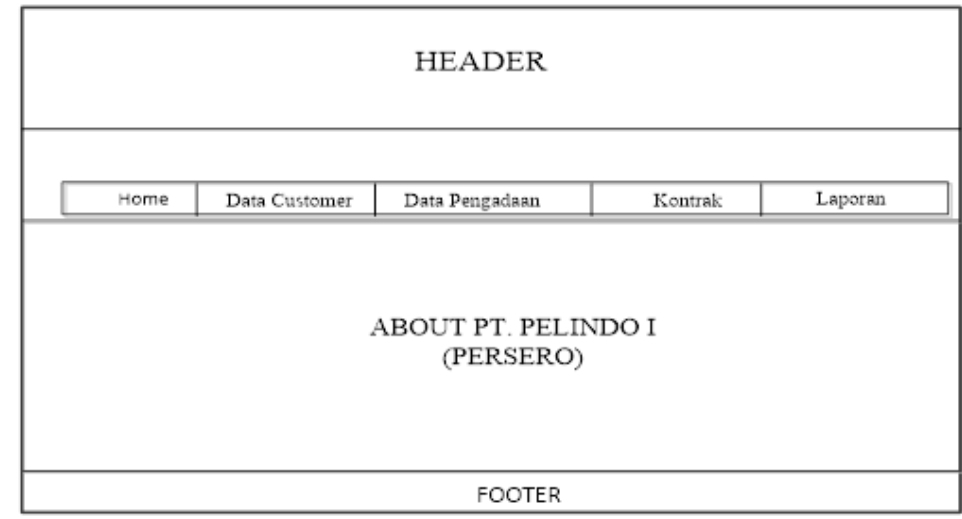

Gambar 5. GUI Storyboard 
JURNAL MEDIA INFORMATIKA BUDIDARMA

Volume 5, Nomor 2, April 2021, Page 387-397

ISSN 2614-5278 (media cetak), ISSN 2548-8368 (media online)

Available Online at https://ejurnal.stmik-budidarma.ac.id/index.php/mib DOI 10.30865/mib.v5i2.2746

\subsection{Use Case Modelling}

Langkah selanjutnya pada metode Iconix Process, adalalah membuat use case yang digunakan untuk menjelaskan hubungan timbal balik antara pengguna dengan sistem. Use case dibagi menjadi 2 yaitu use case text dan use case diagram. Ada 3 aktor pada sistem yang akan dirancang yaitu staff, customer dan pimpinan. Pada Gambar 6 menjelaskan tentang use case staff. Staff bertugas untuk memasukkan data customer, data pengadaan, data kontrak dan laporan. Gambar 7 menjelaskan tentang use case customer. Customer hanya melihat data data customer, data pengadaan dan data kontra. Sedangkan pada Gambar 8 merupakan use case dari pimpinan yang hanya dapat melihat laporan secara keseluruhan.

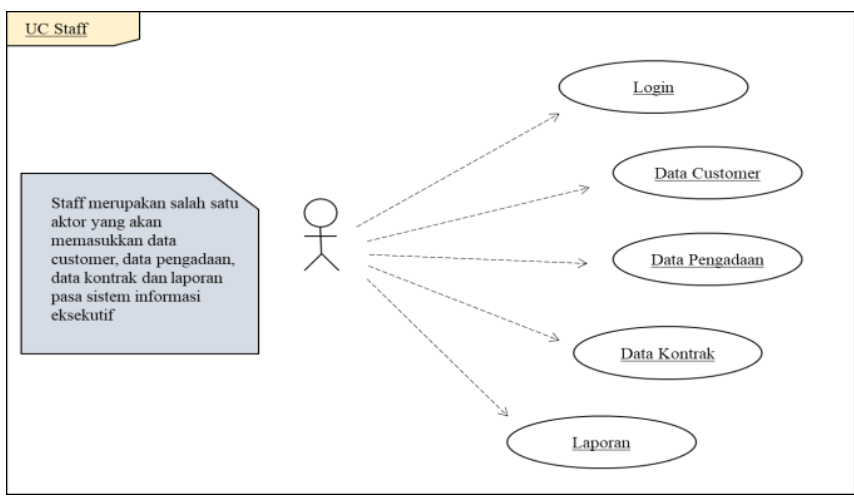

Gambar 6. Use Case Staff

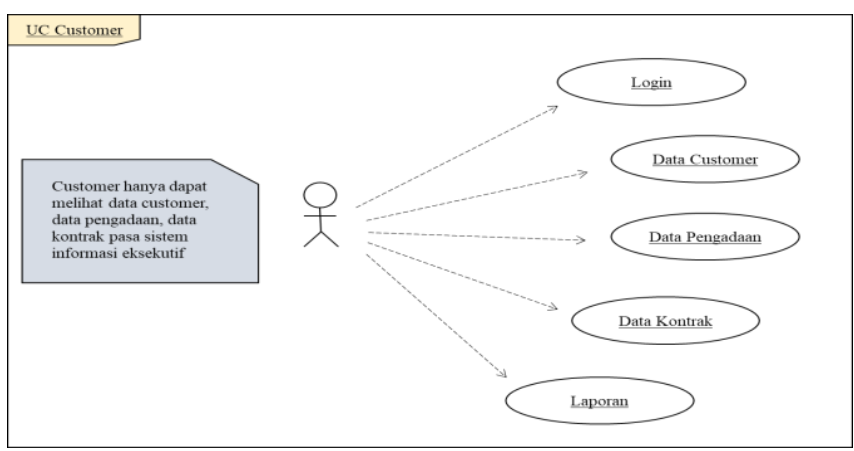

Gambar 7. Use Case Customer

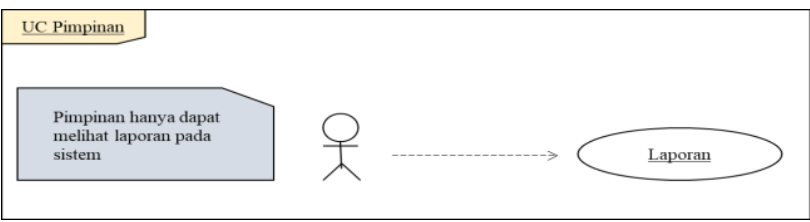

Gambar 8. Use Case Pimpinan

\subsection{Robustness Diagram}

Setelah proses desain selesai, Langkah selanjutnya adalah membuat robustness diagram. Desain yang telah selesai dilakukan pada langkah sebelumnya akan diimplementasikan pada pengkodean. Pada gambar 9 menjelaskan tentang use case staff. Gambar 10 merupakan use case customer dan gambar 11 merupakan use case pimpinan.

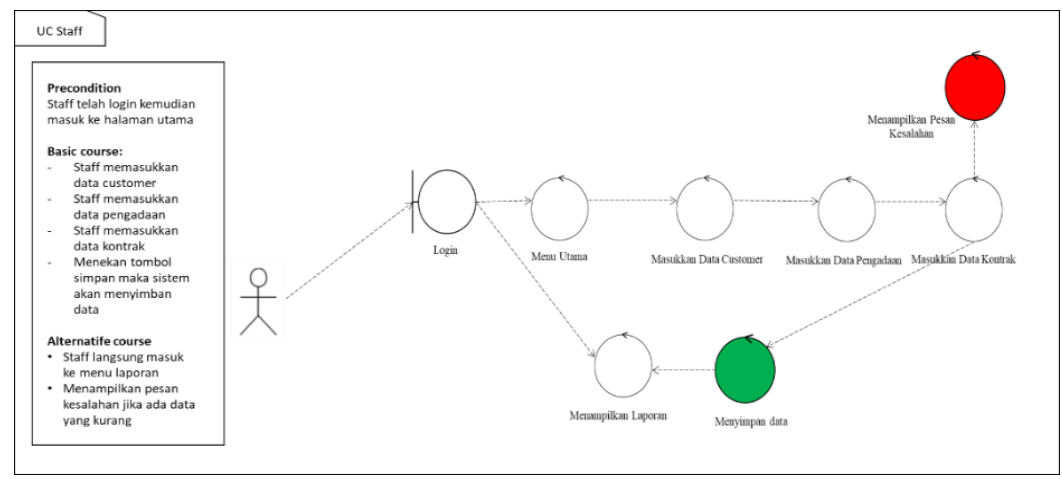

Gambar 9. Use Case Pimpinan

Dedek Indra Gunawan Hutasuhut, Copyright (C2021, MIB, Page 392 
ISSN 2614-5278 (media cetak), ISSN 2548-8368 (media online)

Available Online at https://ejurnal.stmik-budidarma.ac.id/index.php/mib DOI 10.30865/mib.v5i2.2746

Gambar 9 di atas adalah use case staff yang menjelaskan kegiatan-kegiatan yang dilakukan staff pada aplikasi. Untuk mengakses aplikasi, staff harus login terlebih dahulu baru kemudian dapat mengakses menu utama, memasukkan data customer, memasukkan data pengadaan, memasukkan data kontak, menyimpan data dan menampilkan laporan.

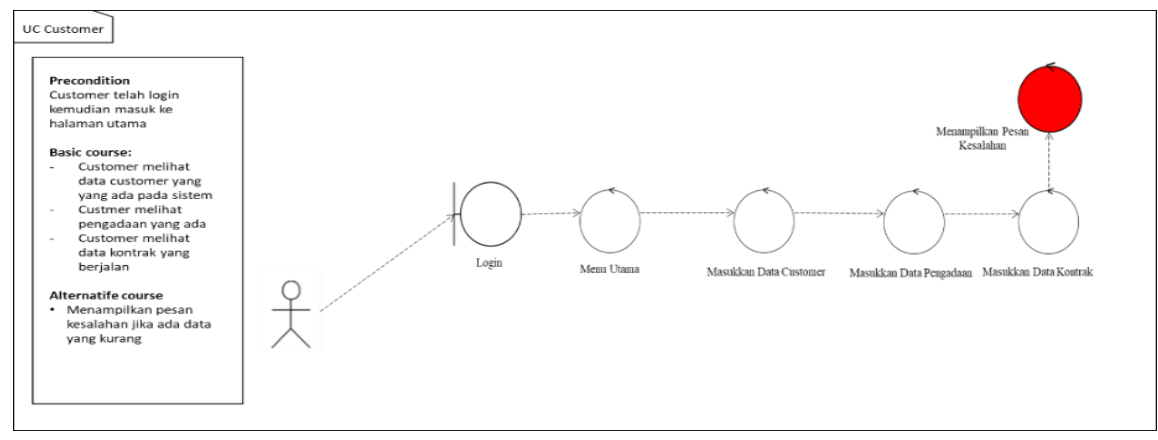

Gambar 10. Use Case Pimpinan

Gambar 10 merupakan use case customer yang menjelaskan kegiatan-kegiatan yang dapat dilakukan oleh customer pada aplikasi. Untuk mengakses aplikasi, customer harus login terlebih dahulu. Setelah login customer akan langsung masuk ke menu utama. Pada menu utama terdapat menu untuk memasukkan data customer, memasukkan data pengadaan dan memasukkan data kontrak.

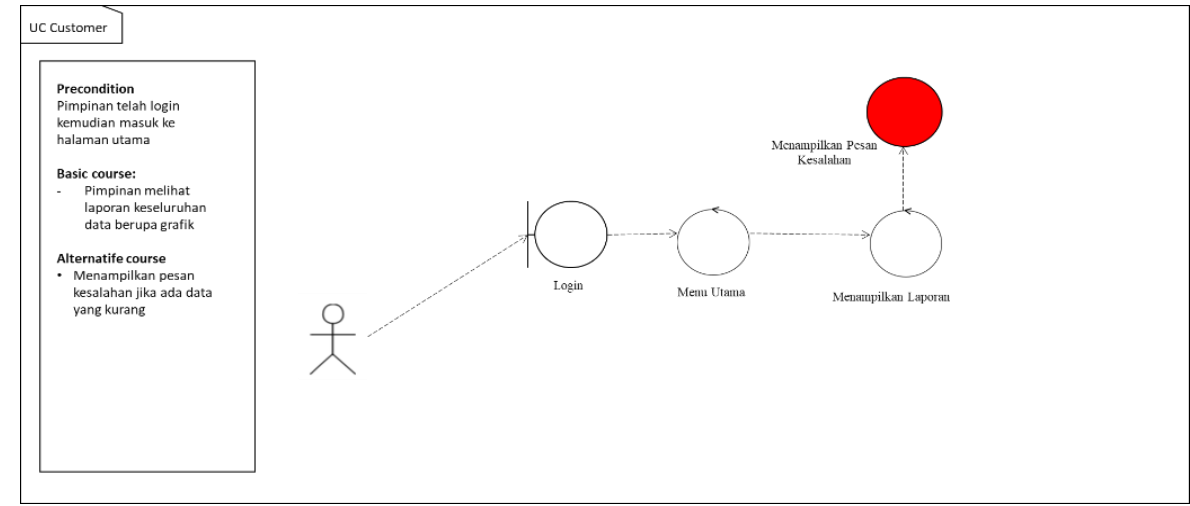

Gambar 11. Use Case Pimpinan

Gambar 11 merupakan use case pimpinan yang menjelaskan kegiatan-kegiatan yang dapat dilakukan oleh pimpinan pada aplikasi. Untuk mengakses aplikasi, pimpinan harus login terlebih. Setelah login pimpnan akan langsung masuk ke menu utama. Pada menu utama pimpinan hanya dapat menampilkan laporan berupa grafik.

\subsection{Sequence Diagram}

Langkah keempat pada Iconix Process adalah membuat Sequence Diagram. Sequence diagram akan menampilkan interaksi antar object dalam sebuah urutan. Pada gambar 12 akan menampilkan sequence diagram interaksi antar object untuk staff dan pimpinan. Sedangkan pada gambar 13 akan menampilkan sequence diagram untuk customer.

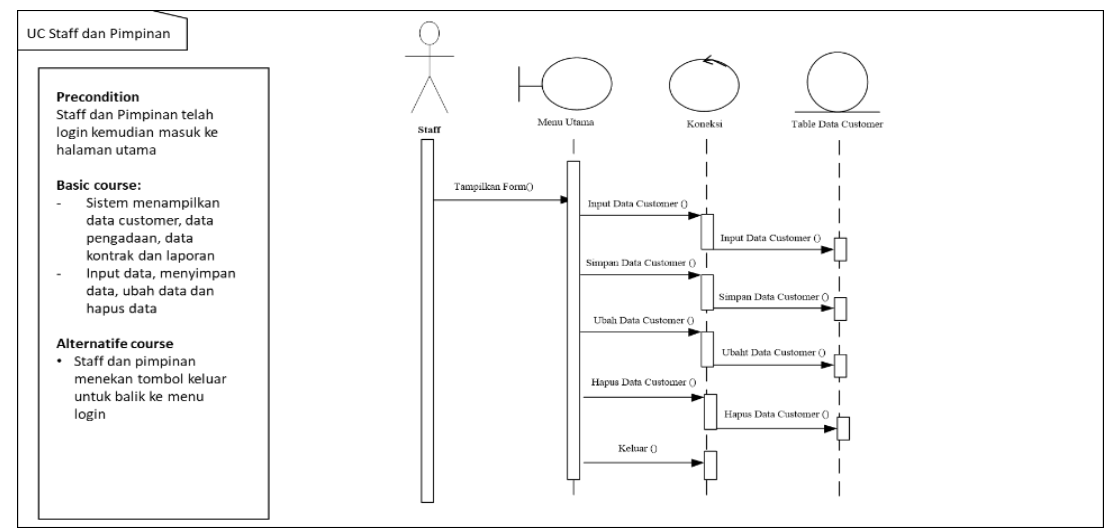

Gambar 12. Sequence Diagram Staff/ Pimpinan 
JURNAL MEDIA INFORMATIKA BUDIDARMA

Volume 5, Nomor 2, April 2021, Page 387-397

ISSN 2614-5278 (media cetak), ISSN 2548-8368 (media online)

Available Online at https://ejurnal.stmik-budidarma.ac.id/index.php/mib DOI 10.30865/mib.v5i2.2746

Gambar 12 merupakan sequence diagram untuk staff dan pimpinan. Langkah ini pada iconix process akan memuat 3 tahapan yaitu precondition, basic course dan alternatife course. Precondition pada sequence diagram staff menjelaskan kondisi sebelum staff dan pimpinan login. Setelah login maka akan masuk ke halaman utama. Basic course menjelaskan kegiatan yang dapat dilakukan nantinya pada sistem seperti input data, hapus data dan keluar. Sedangkan alternatife course jika staff dan pimpinan telah selesai menggunakan sistem maka dapat menekan tombol logout.

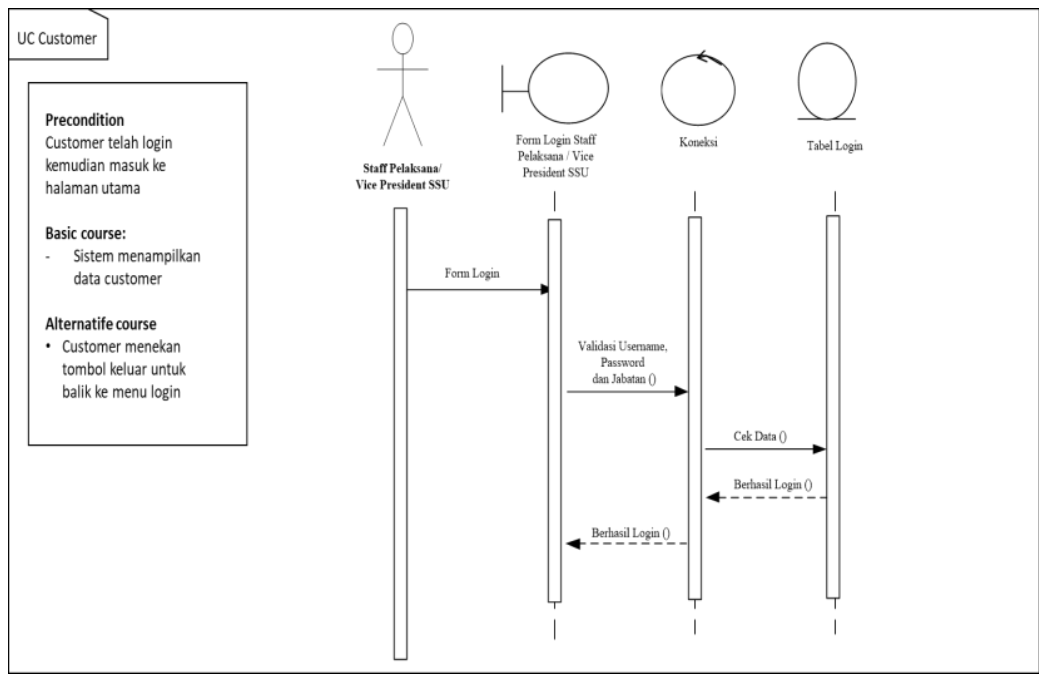

Gambar 13. Sequence Diagram Customer

Gambar 13 merupakan sequence diagram untuk customer. Precondition pada sequence diagram customer menjelaskan kondisi sebelum customer login. Setelah login maka akan masuk ke halaman utama. Basic course pada customer hanya menampilkan data customer. Sedangkan alternatife course pada customer adalah jika customer telah selesai menggunakan sistem maka dapat menekan tombol logout.

\subsection{Implemenasi Program}

1. Tampilan Form Login

Saat karyawan atau pimpinan ingin masuk ke aplikasi maka harus login dengan username dan password yang telah diberikan.

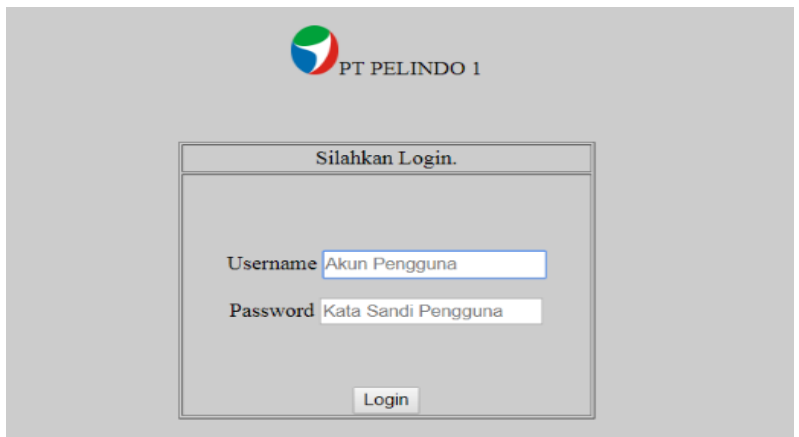

Gambar 14. Tampilan Form Login

2. Tampilan Form Menu

Menampilkan menu-menu yang terdapat pada aplikasi seperti home, data customer, data pengadaan, jadwal lelang, penetapan pemenang, kontrak dan laporan.

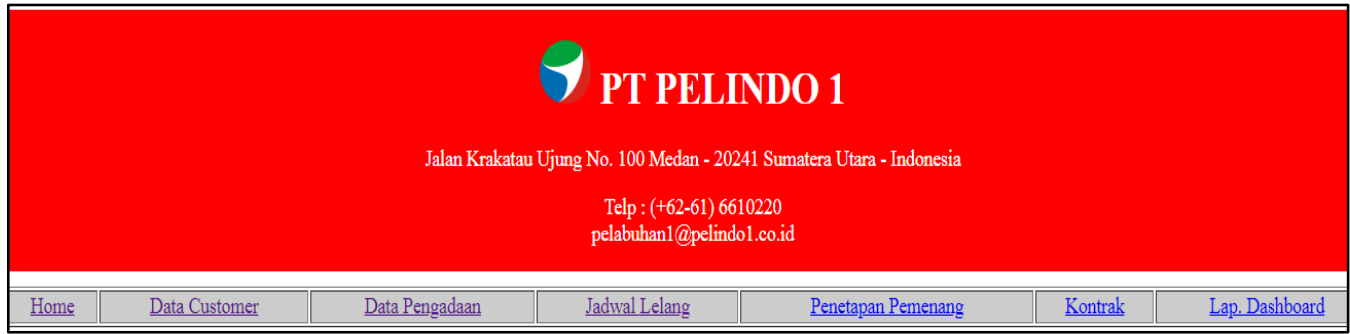

Gambar 15. Tampilan Form Menu 
JURNAL MEDIA INFORMATIKA BUDIDARMA

Volume 5, Nomor 2, April 2021, Page 387-397

ISSN 2614-5278 (media cetak), ISSN 2548-8368 (media online)

Available Online at https://ejurnal.stmik-budidarma.ac.id/index.php/mib DOI 10.30865/mib.v5i2.2746

3. Tampilan Form Data Customer

Menampilkan informasi tentang data customer yang mengikuti lelang pekerjaan dan pengadaan barang seperti ID Customer, Nama Customer, Nama Perusahaan, Alamat Perusahaan, Email, No. Telepon. Pada saat ada cutomer baru karyawan dapat melakukan penambahan data. Apabila ingin mencari data maka dapat menggunakan fasilitas cari.

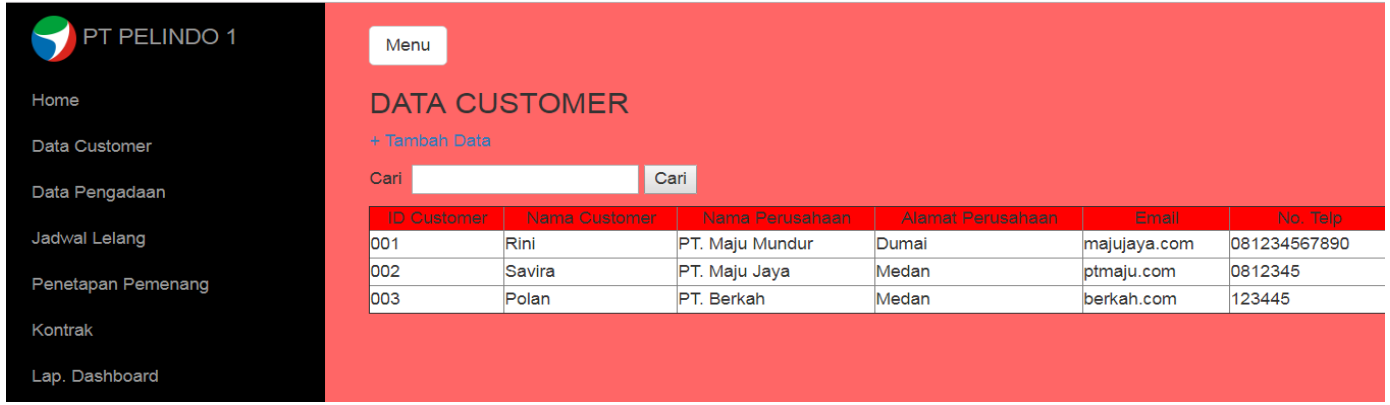

Gambar 16. Tampilan Form Data Customer

4. Tampilan Form Data Pengadaan

Menampilkan informasi tentang data pengadaan yang telah berjalan seperti ID Pengadaan, ID Customer, Perihal, Rincian Harga, Periode Awal, Periode Akhir, Opsi yang berfungsi untuk edit data atau hapus data. Sama halnya dengan form data customer, apabila PT. Pelindo I ingin menambahkan pengadaan pekerjaan atau pengadaan barang maka dapat menambah data. Untuk mencari data dapat dilakukan dengan fasilitas cari yang ada pada form.

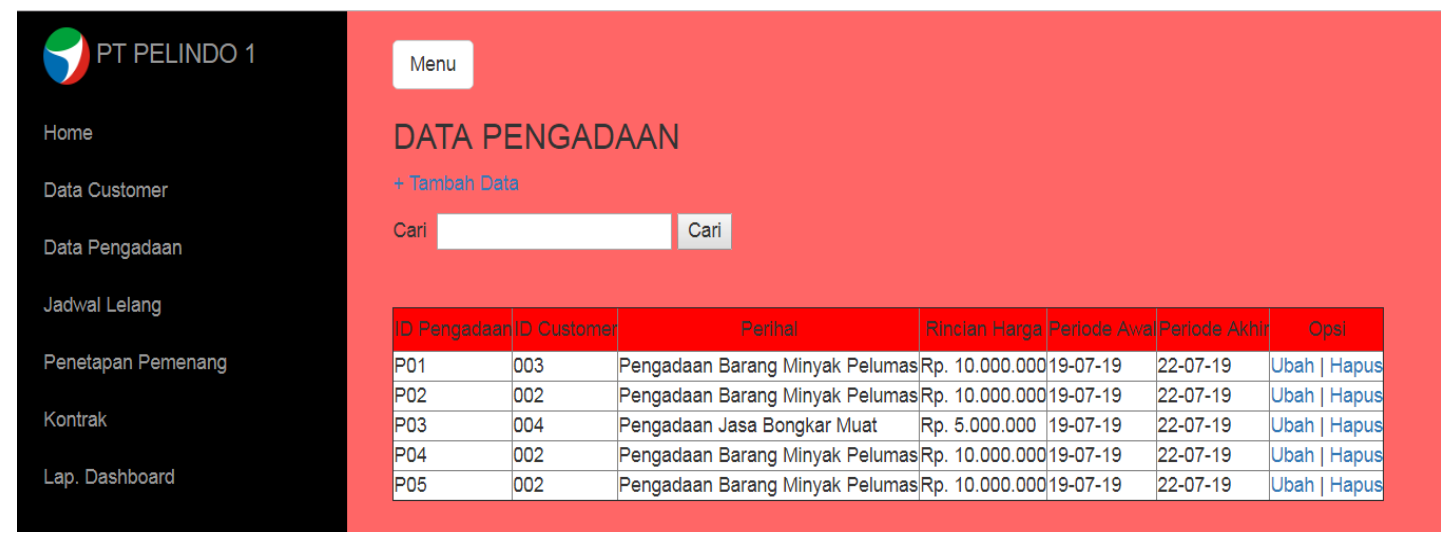

Gambar 17. Tampilan Form Data Pengadaan

5. Tampilan Form Kontrak

Menampilkan informasi tentang data kontrak yang berjalan seperti ID Kontrak, Status, Perihal, Jumlah permintaan, Opsi. Customer yang telah disetujui untuk melakukan pekerjaan atau pengadaan barang maka dimasukkan di form ini.

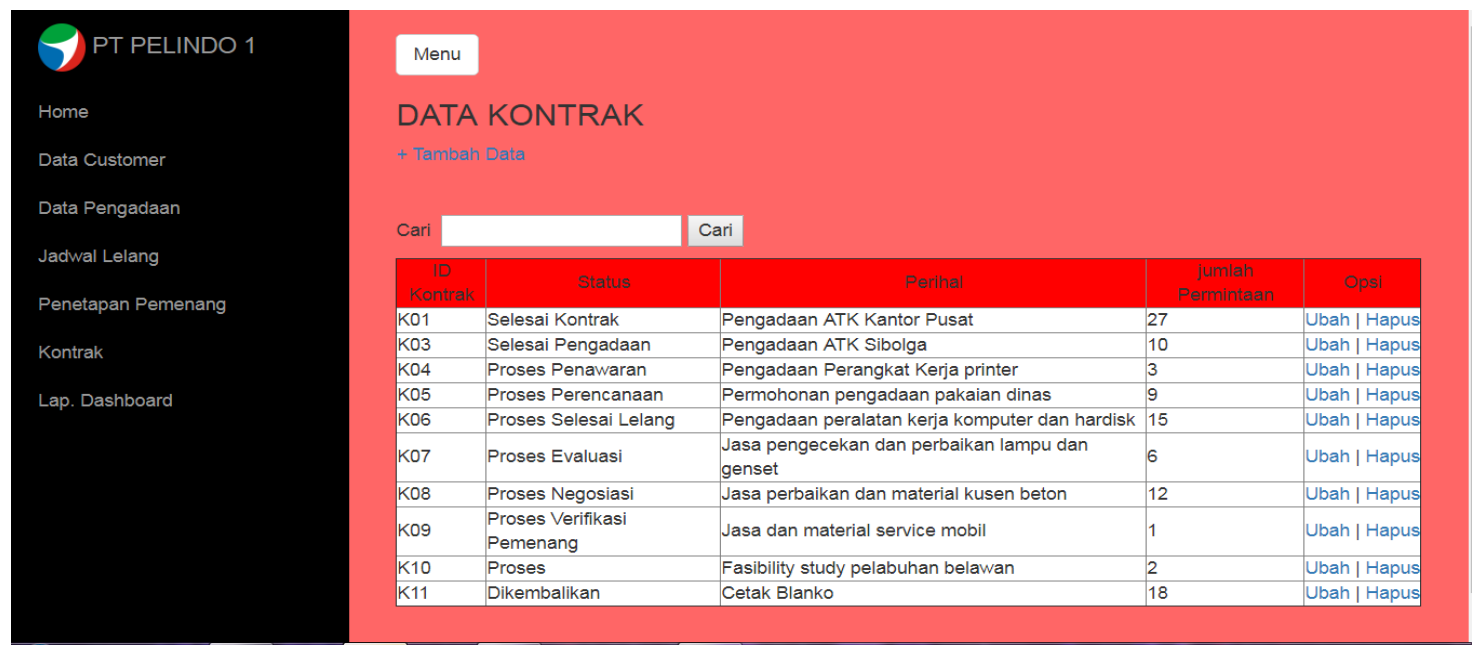

Gambar 18. Tampilan Form Data Kontrak 
JURNAL MEDIA INFORMATIKA BUDIDARMA

Volume 5, Nomor 2, April 2021, Page 387-397

ISSN 2614-5278 (media cetak), ISSN 2548-8368 (media online)

Available Online at https://ejurnal.stmik-budidarma.ac.id/index.php/mib

DOI 10.30865/mib.v5i2.2746

6. Tampilan Form Laporan

Menampilkan grafik laporan berupa status yang telah selesai, masih proses, gagal dan dikembalikan yang terlihat pada Gambar 10 .

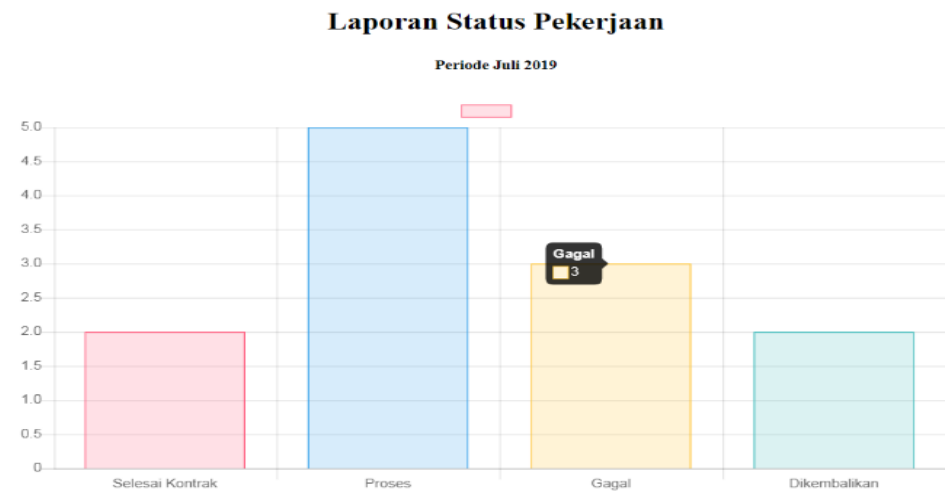

Gambar 19. Tampilan Form Laporan

Dengan dibangunnya sistem informasi eksekutif akan membantu pimpinan untuk mengambil keputusan secara cepat berdasarkan grafik yang terdapat pada sistem[20]. Hasil sama juga disebutkan pada [21] yang menampilkan laporan sistem informasi eksekutif berupa grafik dengan tingkat keakuratan $100 \%$.

\section{KESIMPULAN}

Dari hasil penelitian yang telah dilakukan pada PT. Pelindo I menggunakan Sistem Informasi Eksekutif maka dapat disimpulkan bahwa Sistem informasi eksekutif dibangun berbasis web dengan menggunakan bahasa pemrograman PHP dan database MySql menggunakan data tahun 2019 sesuai dengan kebutuhan PT. Pelindo I. Sistem Informasi Eksekutif menampilkan Status Pekerjaan dan Pengadaan Barang berdasarkan hasil lelang dapat mengelola data pengadaan dan kontrak sehingga menghasilkan laporan yang akurat. Laporan yang dihasilkan dapat dilihat oleh pimpinan. Metode Iconix Process dapat membantu menyelesaikan aplikasi secara efektif. Laporan yang ditampilkan pada sistem informasi eksekutif berupa grafik status pekerjaan dan pengadaan barang yang telah selesai kontrak, sedang proses berjalan, gagal dan dikembalikan sehingga membantu eksekutif untuk menentukan kebijakan. Customer dapat melihat informasi tentang data pengadaan yang berhasil menang dalam pelelangan yang diberikan oleh PT. Pelindo I secara langsung.

\section{UCAPAN TERIMAKASIH}

Pada penelitian ini penulis mengucapkan banyak terima kasih kepada PT. Pelindo I yang telah membantu memberikan data dan bersedia untuk diwawancarai.

\section{REFERENCES}

[1] E. W. Guntari, A. S. Permana, and F. R. Umbara, "Prototype Sistem Informasi Eksekutif Dosen di Perguruan Tinggi Swasta ABCD," JUMANJI (Jurnal Masy. Inform. Unjani), vol. 3, no. 02, p. 53, 2020, doi: 10.26874/jumanji.v3i02.65.

[2] A. B. Putra, S. Mukaromah, Agussalim, Y. Lusiarini, M. I. Rizky, and P. Y. Bestari, "Design and Development Executive Information System Application with Drilldown and What-If Analysis features," J. Phys. Conf. Ser., vol. 1569, no. 2, 2020, doi: 10.1088/1742-6596/1569/2/022050.

[3] M. H. Prayitno, "Sistem Informasi Eksekutif Pemasaran Dengan Metode Drill Down," J. Kaji. Ilm., vol. 17, no. 3, pp. 105-110, 2017, [Online]. Available: http://www.jurnal.ubharajaya.ac.id/index.php/kajian-ilmiah/article/view/105-110.

[4] D. I. G. Hts, "Penerapan Algoritma C4.5 Untuk Penerimaan Siswa Baru Pada SMA Al-Azhar Medan," J-SAKTI (Jurnal Sains Komput. dan Inform., vol. 2, no. 2, p. 130, 2018, doi: 10.30645/j-sakti.v2i2.76.

[5] Samsir, D. I. G. Hts, and S. Z. Harahap, "SPK Untuk Pemilihan Kepala Sekolah Menggunakan Metode Saw dan Profile Matching," vol. 4, no. 1, pp. 7-12, 2020.

[6] I. S. Harumy, T.H.F., "Sistem Penunjang Keputusan Penentuan Jabatan Manager," Semin. Nas. Teknol. Inf. dan Multimed. 2016, pp. 6-7, 2016.

[7] A. Djunaedi, A. Subiyakto, and E. Fetrina, "SISTEM PENDUKUNG KEPUTUSAN PENILAIAN KINERJA PEGAWAI (Studi Kasus : PT . PLN (Persero Distribusi Jakarta Raya Area Pondok Gede))," J. Sist. Inf., vol. 10, no. 1, pp. 37-44, 2017

[8] W. Widayani, K. Kusrini, and H. Al Fatta, "Perancangan Sistem Pendukung Keputusan Penentuan Impor Bawang Merah," Creat. Inf. Technol. J., vol. 2, no. 3, p. 181, 2015, doi: 10.24076/citec.2015v2i3.47.

[9] Y. Primadasa and V. Amalia, "Penerapan Metode Multi Factor Evaluation Process untuk Pemilihan Tanaman Pangan di Kabupaten Musi Rawas,” Sisfo, vol. 07, no. 01, pp. 47-58, 2017, doi: 10.24089/j.sisfo.2017.09.004.

[10] E. Prasetyo, L. Edi Nugroho, and M. Nurtiantara Aji, "Perancangan Data Warehouse Sistem Informasi Eksekutif untuk 
JURNAL MEDIA INFORMATIKA BUDIDARMA

Volume 5, Nomor 2, April 2021, Page 387-397

ISSN 2614-5278 (media cetak), ISSN 2548-8368 (media online)

Available Online at https://ejurnal.stmik-budidarma.ac.id/index.php/mib

DOI 10.30865/mib.v5i2.2746

Data Akademik Program Studi,” J. Nas. Tek. Elektro dan Teknol. Inf. UGM, vol. 1, no. 3, pp. 13-20, 2015.

[11] J. Christian, "Model Data Warehouse Dengan Service Oriented Architecture Untuk Menunjang Sistem Informasi Eksekutif," J. Telemat. MKOM, vol. 2, no. 2, pp. 103-115, 2015.

[12] A. Nurwidyantoro, B. Hakim, and E. P. Utomo, "Perancangan Sistem Informasi Eksekutif (studi kasus di UGM)," Snati Uii, pp. 43-47, 2013.

[13] E. Papageorgiou and H. De Bruyn, "Creating strategic value through executive information systems: An exploratory study," Proc. 3rd Eur. Conf. Inf. Manag. Eval. ECIME 2009, vol. 13, no. 1, pp. 380-399, 2009.

[14] K. D. Dharmawan and W. S. Sari, "Pembangunan Situs Web Menggunakan Metode Iconix Process Untuk Strategi Penjualan Komputer Pada Cv . Citra Mandiri Semarang,” (Journal Inf. Syst., vol. 1, no. 2, pp. 193-201, 2016, [Online]. Available: https://publikasi.dinus.ac.id/index.php/joins/article/view/1309.

[15] M. Amirul, M. Achmad, K. Slamet, and H. Eny, "Improvement of Human Resources Performance Through Online Presence Applications Based on Android Using UML - Iconix process.” ACHITS, Surabaya, 2019, doi: DOI 10.4108/eai.30-7-2019.2287605.

[16] A. Pratama, S. Mukaromah, S. A. Ithriah, and E. M. Safitri, "Entrepreneurship Information System Design with ICONIX Process for a Student Business Unit Marketplace," J. Phys. Conf. Ser., vol. 1569, no. 2, 2020, doi: 10.1088/1742$6596 / 1569 / 2 / 022041$

[17] R. A. F. Ismubandono, W. Hayuhardhika, N. Putra, and D. Pramono, "Analisis dan Perancangan Sistem Informasi Eksekutif Dashboard Data E- Government berbasis Service pada Pemerintah Kabupaten Sidoarjo,” J. Pengemb. Teknol. Inf. dan Ilmu Komput., vol. 3, no. 11, pp. 10788-10796, 2019.

[18] S. Widiyastuti, L. A. Abdillah, and K. Zaini, "Sistem Informasi Eksekutif Bagian Kepegawaian pada PT Pelindo II (Persero) Palembang," Semin. Nas. Teknol. Informasi, Komun. dan Manag., vol. 5, no. 01, pp. 165-171, 2014, [Online] Available: http://eprints.binadarma.ac.id/2225/1/Abdillah2014_SEMNASTIK_SIE_Kepegawaian_PelindoII.pdf.

[19] S. Mukaromah, A. B. Putra, and N. C. Wibowo, "Analisis dan Perancangan Sistem Informasi Logbook dengan Iconix Process," Rekayasa Teknol. Ind. dan Inf. 2017, pp. 130-135, 2017, [Online]. Available: https://journal.sttnas.ac.id/ReTII/article/download/601/506.

[20] I. P. Komara, T. P. Hendro, and F. Rinaldi, "Kata kunci :," Pros. SNATIF Ke -4, pp. 349-355, 2017

[21] F. Sulistyo, S. Andryana, and W. Winarsih, "Sistem Informasi Eksekutif Fakultas Teknologi Komunikasi dan Informatika Universitas Nasional,” J. Media Inform. Budidarma, vol. 4, no. 3, p. 544, 2020, doi: 10.30865/mib.v4i3.2137. 